\title{
NOTES
}

\section{SECTION 8(d) OF LMRA AS A BAN ON STRIKES BEFORE CONTRACT TERMINATION*}

Sectron $8(d)$ of the Labor-Management Relations Act limits a union's right to strike when bargaining for contract modification. ${ }^{1}$ Subsection 8(d) (1) provides that the union must notify the employer of its proposed modifications "sixty days prior to the expiration date" of the contract." Subsection 8(d) (4) requires the union to continue the existing contract in effect, without striking "for a period of sixty days after such notice is given or until the expiration date of such contract, whichever occurs later."3 Union members who "strike within the sixty-day period" lose their rights as employees under the LMRA.4 A strike failing to comply with Section 8(d) constitutes an unfair labor practice, which may be stopped by a cease and desist order.5 Conflict has developed

"Local No. 3, United Packinghouse Workers of America, CIO v. NLRB, 210 F.2d 325 (8th Cir. 1954), denying enforcement to Wilson \& Co., 105 N.L.R.B. No. 128, 32 LAv. REL. Ref. Man. 1371 (June 30, 1953), cert. denied, 75 Sup. Ct. 36 (1954); Lion Oil Co., 109 N.L.R.B. No. 106, 34 LAB. ReL. REF. MAN. 1410 (August 5, 1954).

For discussions of these cases, see 54 CoL. L. Rev. 1006 (1954); CCH LAp. LAw REp. If 50,008, 50,020 (1954); 33 Lab. Rez. Rep. Anal. 72 (1954); 34 id. 61 (1954).

1. "[T] $]$ he duty to bargain collectively shall also mean that no party to such contract shall terminate or modify such contract, unless the party desiring such termination or modification-

"(1) serves a written notice upon the other party to the contract of the proposed termination or modification sixty days prior to the expiration date thereof, or in the event stch contract contains no expiration date, sixty days prior to the time it is proposed to make such termination or modification;

“....

"(4) continues in full force and effect, without resort to strike or lockout, all the terms and conditions of the existing contract for a period of sixty days after such notice is given or until the expiration date of such contract, whichever occurs later." 61. STAT. 142 (1947), 29 U.S.C. §158(d) (1952).

2. Ibid.

3. Ibid. The union must also notify the Federal Mediation and Conciliation Service, thirty days after the $\S 8$ (d) (1) notice, of the existence of a dispute. Id. at 142, 29 U.S.C. $\S 158$ (d) (3) (1952).

4. 61 STAT. 143 (1947), 29 U.S.C. $\S 158$ (d) (1952). The principal right lost is the employee's right under $\S 10$ (c) to reinstatement at the end of the strike. Bocing Airplane Co. v. NLRB, 174 F.2d 988 (D.C. Cir. 1949) ; Local No. 3, United Packinghouse Workers of America, CIO v. NLRB, 210 F.2d 325 (8th Cir. 1954). Normally, employees striking for contract modifications remain employees under the LMRA and are guaranteed reinstatement at the end of a strike, subject to the employer's right to replace them during the strike. See NLRB v. Mackay Radio \& Telegraph Co., 304 U.S. 333 (1938); Cusano v. NLRB, 190 F.2d 898 (3d Cir. 1951) ; NLRB v. Remington Rand, Inc., 130 F.2d 919 (2d Cir. 1942).

5. It is an unfair labor practice for a union to refuse to bargain collectively with an employer. 61. Stat. 141 (1947), 29 U.S.C. $\$ 158(b)$ (3) (1952). Included in the duty 
as to whether the "whichever is later" clause prevents a union from striking during the term of a collective bargaining agreement.

The National Labor Relations Board in Wilson \& $C 0^{\circ}$ took the position that bargaining strikes ${ }^{7}$ before contract termination were valid under Section $S(d)$ if the union gave sixty days' notice. The Packinghouse lVorkers struck twelve weeks after giving notice of intended contract modifications. ${ }^{8}$ Since the strike occurred fourteen months before the collective bargaining agreement was to terminate, ${ }^{9}$ Wilson claimed that the strike failed to comply with Section 8 (d) (4) and was therefore an unfair labor practice. ${ }^{10}$ The NLRB, however, held that the strike was valid since it took place more than sixty days after notice. ${ }^{11}$

In Local No. 3, United Packinghouse Workers of America, CIO v. NLRB, ${ }^{12}$ a companion case arising from the same nation-wide strike, the Eighth Circuit interpreted Section 8 (d) as outlawing all bargaining strikes occurring prior to contract termination. After bargaining pursuant to an amending clause in its contract, ${ }^{13}$ the Packinghouse Workers struck thirteen weeks after notice but

to bargain collectively is compliance with $\$ S(d)$. See note 1 supro. Thus a strike in violation of $\S 8$ (d) is an unfair labor practice. The NLRB, either on its own initiative or upon petition by an employer, can order the strikers to cease and desist from continuing the strike. 61 STAT. 147 (1947), 29 U.S.C. $\$ 160$ (c) (1952); Report of Trial Examiner, Local No. 49, United Packinghouse Workers of America, CIO, 89 N.L.R.B. 310, 338 (1950). The strike may also be enjoined pending the NLRB's determination. Curry' v. Union De Trabajadores De La Industria, \&6 F. Supp. 707 (D.C.P.R. 1949). Cf. Mountain States Div. No. 17 v. Mountain States T. \& T. Co., 81 F. Supp. 397 (D. Colo. 1948) (employer can be enjoined from terminating agreement without giving notice required both by contract and $\S S(d)$ ).

6. Local No. 49, United Packinghouse Workers of America, CIO, and Wilson \& Co., S9 N.L.R.B. 310 (1950) (hereinafter referred to as Wilson).

7. The term "bargaining strike" will be used to denote strikes for the purpose of modifying or terminating a collective bargaining contract.

8. Local No. 49, United Packinghouse Workers of America, CIO, 89 N.L.R.B. 310, 311 (1950).

9. The contract was to terminate Mfay 24, 1949. Notice was given December 26, 1947, and the strike occurred March 16, 1948. Ibid.

10. Id. at 324 .

11. Id. at 318. Two members of the Board concurred, stating that no notice period was required for strikes during the term of a contract. They reasoned that, since $\$ 8(d)$ (1) referred only to notice at the termination of an agreement, it imposed no notice requirement for bargaining strikes occurring prior to contract termination. Id. at 319 (Herzog), 323 (Miurdock).

12. 210 F.2d 325 (Sth Cir. 1954), denying enforcentent to Wilson \& Co., 105 N.L.R.B. No. 128, 32 Lab. Rez. Ref. MAan. 1371 (June 30, 1953), cert. denicd, 75 Sup. Ct. 36 (1954).

13. "This agreement may be reopened by either party solely on the issue of general wages . . once during the period from August 11, 1947, to August 11, 1948, by written notice... thirty (30) days prior to the date on which it is desired to commence negotiations." Master Agreement between Wilson \& Co. and United Packinghouse Workers $\$ 85$ (1940). The existence of the reopening clause in Packinghouse Workers was not mentioned by the Eighth Circuit. See Local No. 3, United Packinghouse Workers of America, CIO v. NLRB, 210 F.2d 325 (8th Cir. 1954). 
five months before the expiration date of the contract. ${ }^{14}$ Wilson refused to reinstate certain strikers at the end of the three-month strike. ${ }^{15}$ The union petitioned the NLRB, which ordered reinstatement, relying on its decision in Wilson to validate the strike under Section $8(\mathrm{~d}) .{ }^{10}$ The Eighth Circuit rejected the NLRB interpretation by a literal reading of Section $8(d)(4)$. The Court construed 8 (d) (4) as preventing a union from striking for sixty days after notice or until the expiration of the contract, whichever came later. ${ }^{17} \Lambda$ lthough the Packinghouse Workers waited for sixty days, they struck before the termination date of the agreement, thereby violating Section $8(\mathrm{~d}) .18$ As a result, the strikers lost their status as employees and the court denied them reinstatement. $^{19}$

In Lion Oil Co. ${ }^{20}$ a newly constituted Board adopted a third position, stating that Section 8(d) outlawed all bargaining strikes before contract termination except those which occurred at the time of contract modification. The contract in Lion Oil could be amended after a certain date upon sixty days' notice by either party, with an additional sixty-day notice required to terminate the agreement. ${ }^{21}$ The Oil Workers gave the prescribed notice to amend and waited eight months before striking. ${ }^{22}$ Since the union gave no notice of termination, the strike took place before the contract's termination date. ${ }^{23}$ The NLRB adopted the interpretation given Section 8(d) in Packinghouse Workers, ${ }^{24}$ but

14. The agreement was terminable on August 11, 1948. The union gave notice of intended contract modifications on December 19, 1947, and struck on March 16, 1948. Wilson \& Co., 105 N.L.R.B. No. 128, p. 4, 32 Lab. Rel. Ref. MaN. 1371, 1372 (June 30, 1953).

15. Local No. 3, United Packinghouse Workers of America, CIO v. NLRB, 210 F.2d 325, 327 (8th Cir. 1954). One of the company's reasons for refusing reinstatement was that these men had engaged in acts of violence during the strike. Id. at 327, 330. Individual acts of violence, even during a valid strike, give the employer the right to discharge the wrongdoers. NLRB v. Fansteel Metallurgical Corp., 306 U.S. 240 (1939); Rubin Bros. Footwear Inc. v. NLRB, 203 F.2d 486 (5th Cir. 1953).

16. Wilson \& Co., 105 N.L.R.B. No. 128, pp. 4, 5, 32 LAB. Rel. REF. MAN. 1371, 1372 (June 30,1953). For earlier NLRB decision in Wilson see text at notes 6-11 supra.

17. Local No. 3, United Packinghouse Workers of America, CIO v. NLRB, 210 F.2d 325, 331-2 (8th Cir. 1954). In another companion case, United Packing House Workers of America v. Wilson \& Co., 80 F. Supp. 563, 569 (N.D. Ill. 1948), a district court gave $\S 8(\mathrm{~d})$ an interpretation similar to that of the Eighth Circuit. See note 33 infra.

18. Local No. 3, United Packinghouse Workers of America, CIO v. NLRB, 210 F.2d 325, 333 (8th Cir. 1954).

19. Ibid. The court held alternatively that the employees in question had engaged in acts of violence and therefore were not entitled to reinstatement. Id. at 330-1. See note 15 supra.

20. 109 N.L.R.B. No. 106, 34 LAB. Red. Ref. Man. 1410 (August 5, 1954).

21. Id. at 2 and n.I, 34 LAB. ReL. ReF. MAN. at 1410.

22. Notice of the union's proposed contract modification was given the company on August 24, 1951. The strike occurred April 30, 1952. Id. at 2, 34 LAB. REl. REF. MAN. at $1410,1411$.

23. Proposed Findings of Fact, Lion Oil Co., pp. 6, 35, aff'd, 109 N.L.R.B. No. 106, p. 1, 34 Lab. Red. Ref. MaN. 1410 (August 5, 1954).

24. Lion Oil Co., 109 N.L.R.B. No. 106, p. 10, 34 Lab. ReI. ReF. MIN. 1410, 1413 (August 5, 1954). 
defined the term "expiration date" in $8(d)(4)$ as including "modification date." 25 Since the Oil Workers gave sixty days' notice and struck at a time when the terms of their contract were subject to modification, the NLRB held that the strike complied with Section 8 (d) even though it took place before the contract terminated. ${ }^{26}$

Packinghouse Workers relied on the "plain wording" of Section S(d) (4) to outlaw bargaining strikes prior to contract termination. ${ }^{27}$ However, other provisions of Section 8 (d) raise serious doubt as to the meaning of the section. Section 8 (d) deprives only those who strike within the sixty-day notice period of their employee status, without assigning any penalty to those who strike after notice but before contract termination. ${ }^{28}$ It seems anomalous that Congress would penalize only strikers during the notice period if strikes both before notice and before contract termination violate Section $8(d) .90$ Furthermore, 8 (d) provides that neither unions nor employers have a duty to bargain over modification of contract issues if the modification is to take effect "before such terms and conditions can be reopened under the provisions of the contract."30 If Packinghouse Workers is followed, Section $S(d)$ inconsistently implies an affirmative duty to bargain at the time of contract amending ${ }^{31}$ and

25. Id. at 6, 34 LAB. REL. REF. MAN. at 1412 .

26. Id. at 9,34 LAB. REL. REF. MIAN. at 1413. One member, concurring, reaffirmed Wilson, see text at note 11 supra, and stated that all bargaining strikes during the term of contracts were valid if sixty days' notice was given. Id. at 16, 34 LAB REL REF. MAs:3. at 1415 (Peterson).

Another member affirmed his position in $W$ ilson, stating that no notice was required for pre-termination bargaining strikes, notice being required only when an agreement was to be modified or terminated on its expiration date. See note 11 supra. However, he found that the union's notice of modification had placed the parties under a new contract terminable at will. Because the union failed to give notice of termination when it struck under the new contract, and because its prior notice of modification was ineffectual, he held the union in violation of $\S 8$ (d) and its members not entitled to reinstatement. Id. at 29,30,34 LAB. REI. REF. MAN. at 1419, 1420 (Murdock).

27. Local No. 3, United Packinghouse Workers of America, CIO v. NLRB, 210 F.2d 325, 332 (8th Cir. 1954). Lion Oil concurred in the proposition that the language of $\$ 8$ (d) was plain and unambiguous. Lion Oil Co., 109 N.L.R.B. No. 106, p. 4, 34 LAB. REz. REF. Mañ. 1410, 1411 (August 5, 1954).

28. See text at note 4 sipra.

29. See Local No. 49, United Packinghouse Workers of America, CIO, 89 N.L.R.B. 310-14 (1950). However, even without this statutory penalty, The Eighth Circuit held that the union members had struck in violation of $\S 8(d)$ and were therefore validly denied reinstatement. See notes 4 and 15 supra. When employees engage in an illegal strike, they are not entitled to reinstatement even though there is no specific statutory provision denying them reinstatement. See Mackay Radio \& Telegraph Co., 96 N.L.R.B. 740 (1951); Auto Stove Works, 81 N.L.R.B. 1203 (1949) (individual misconduct). Also see Hoover Co. v. NLRB, 191 F.2d 380 (6th Cir. 1951) (illegal boycott).

30. 61. StaT. 142 (1947), 29 U.S.C. \$158 (d) (1952).

31. Employers and unions have a duty to bargain over provisions included within the amending clause. See Cathey Lumber Co., 86 N.L.R.B. 157, 168 (1949); NLRB v. Sands Manufacturing Co., 306 U.S. 332, 342 (1939). 
yet forbids the right to strike, so essential to enforce such bargaining. ${ }^{\mathbf{2} 2} \mathrm{Al}$ though $8(d)$ (4) itself may be plainly worded, its logical incompatibility with other provisions of $8(d)$ renders the entire section ambigutous.

Both Packinghouse Workers and Lion Oil cited quotations from the legislative history of the LMRA to sustain their position that Section 8 (d) prohibited bargaining strikes prior to contract expiration. ${ }^{33}$ However, inspection of the Act's voluminous record fails to yield any support for the proposition that a pre-termination strike preceded by sixty days' notice violates Section $8(\mathrm{~d}) .{ }^{34}$ Congress failed to consider such strikes when it drafted the section. ${ }^{30}$

32. Union spokesmen claim that few employers will come to terms if not faced with a strike threat. Hearings before Committee on Labor and Public Welfare on S. 55 and S.J. Res. 22, 80th Cong., 1st Sess. 1188 (1947) ; Hearings before Committec on Labor and Pullic Welfare on Revisions in LMRA, 83d Cong., 1st Sess. 474 (1953). Legislators and statesmen agree that the union's right to strike is essential. See statement by Senator Taft in Hartley, Our New National Labor Policy, p. xiv (1945). Sce also Gagliardo, Intrioduction to Collective Bargaining 259 (1953) ; Isaacson, Enforcement of Labor Agrecments by Economic Action, 6 NYU CONFERENCE ON LABOR 69, 71 (1952).

33. The Eighth Circuit's use of quotations from legislative history is misleading. The court cited the Senate Minority report on the LMRA, which stated that $\S 8$ (d) incorporated no-strike clauses in collective bargaining agreements "by legislative fiat." Local No, 3, United Packinghouse Workers of America, CIO v. NLRB, 210 F.2d 325, 332 (8th Cir. 1954). But this section of the report referred only to the statutory prohibition of strikes during the sixty-day notice period, and nowhere implied that a union wottld be prevented from striking after a sixty-day wait. SEN. MIN. ReP. No. 105, pt. 2, 80th Cong., 1st Sess. 21 (1947), 1 NLRB, LEg. Hist. LMRA 483 (1948).

The court quoted Senator Taft as follows: "If such notice is given, the bill provides for no waiting period except during the life of the contract itself." Local No. 3, United Packinghouse Workers of America, CIO v. NLRB, 210 F.2d 325, 332 (8th Cir. 1954). But Taft modified this later in the same statement by declaring that if notice was given less than sixty days before contract termination the waiting period would extend $b c y$ ond the life of the contract. Nowhere in his statement did he consider strikes before termination of the contract. 93 Cong. Rec. 3955 (April 23, 1947), 2 NLRB LEG. HIsT. LMRA 1015 (1948).

The Eighth Circuit cited a district court case arising from the same Packinghouse Workers' strike, in which the union attempted to enjoin Wilson from refusing reinstatement following a strike after notice. The court dismissed the case for lack of jurisdiction. It did declare in dictum, unsupported by precedent or legislative history, that the Packinghouse Workers did not deserve relief since they had violated $\S 8(\mathrm{~d})$ by striking beiore contract termination. United Packinghouse Workers v. Wilson \& Co., 80 F. Supp. 563, 569 (N.D. Ill. 1948). But a later district court case held a bargaining strike valid even though it came before contract termination. See Textile Workers v. Atlantic Cotton Mills, 30 LaAy. REL. ReF. Man. 2400 (M.D. Ga. July 1, 1952).

Lion Oil's relevant citations from legislative history were the same as those in Pacliinghouse Workers. See Lion Oil Co., 109 N.L.R.B. No. 106, p. 5 and n.5, 34 LAD. Rel. REF. MAN. 1410, 1412 (August 5, 1954).

The references to legislative history in Wilson attempted to show that $\$ 8(d)$ permitted pre-termination strikes on sixty days' notice, 89 N.L.R.B. 310, 315, 316 (1950), but they are inconclusive, since none of these statements referred to pre-termination strikes. Congress never considered the application of $\S 8(d)$ to such strikes. See text at notes $34-5$ infra.

34. See the more than 8000 pages of hearings, reports, and debates in Hcarings bcforc Committee on Labor \& Public Welfare on S.55 and S.J. Res.22, 80th Cong., 1st Sess. (1947); Hearings before Committee on Education and Labor on H.R. S, 80th Cong., 1st 
Congressional desire to achieve industrial stability was clearly expressed throughout the hearings on the LMRA. But Congress' attention in this regard was directed at strikes in breach of contract; it made unions involved in these strikes subject to damage suits under Section 301.30 However, Congress specifically refused to declare that strikes in breach of contract were unfair labor practices. ${ }^{37}$ It is unlikely that Congress by Section $S(d)$ intended to invalidate pre-termination bargaining strikes permitted under a contract when it refused to invalidate strikes in breach of contract.

In view of the ambiguity of Section 8(d)'s language and the failure of Congress to consider whether bargaining strikes before contract termination violated the section, the general purpose of Congress in passing Section $\mathbf{S ( d )}$ should govern its application to such strikes. ${ }^{38}$ The hearings and debates indicate that the prohibition of strikes during the notice period was designed primarily to prevent the damaging effect of strikes without warning and to allow a cooling-off period during which differences might be discussed and

Sess. (1947) ; H.R. REP. No. 245, 80th Cong., 1st Sess. (1947) ; SEs. REp. No. 105, 80th Cong., 1st Sess. (1947) ; H.R. Conf. REP. No. 510, 80th Cong., 1st Sess. (1947); NLRB, LEG. HIST. LMRA (1948) (congressional debates). For an esamination of legislative history of $\$ 8(d)$, see CCH LAB. LAw REP. $\|$ 50,00S (1954).

35. See authorities cited note 34 supra.

36. Section 301 of the LMIRA allows suits to be brought in district courts against labor unions for damages caused by the breach of collective bargaining agreements. 61 STAr. 156 (1947), 29 U.S.C. $\$ 185$ (a) (1952). It was to this section of the Act that legislators and committees directed their comments on industrial stability, and it was from these discussions and not from discussions on $\S 8(d)$ that the Eighth Circuit and NLRB obtained the statement that "[i]f unions can break agreements with relative impunity, then such agreements do not tend to stabilize industrial relations." SEN. Rep. No. 105, E0th Cong., 1st Sess. 16 (1947), 1 NLRB LEg. Hist. LMRA 422 (1948). See Local No. 3, United Packinghouse Workers of America, CIO, 210 F.2d 325, 332 (Sth Cir. 1954); Lion Oil Co., 109 N.L.R.B. No. 106, p. 4 and n.13, 34 LAB. Rer. Ref. MIAN. 1410, 1411 (August 5, 1954).

The Eighth Circuit and NLRB confused strikes in breach of contract, covered by $\$ 301$, with those in violation of $\S 8(d)$. They are similar in that both sections cover pre-termination strikes. But a strike in violation of a no-strike clause in a contract can comply with $\S 8(d)$, International Union of Operating Engineers, Local 181 v. Dahlem Construction Co., 193 F.2d 470 (6th Cir. 1951), and a strike violating $\$ 8(d)$ does not necessarily breach the terms of a contract, see Local No. 3, United Packinghouse Workers of America, CIO v. NLRB, 210 F.2d 325 (8th Cir. 1954); and see text at note 19 stipra. Cf. Reed v. Fowick Airflex Co., 86 F. Supp. 822 (N.D. Ohio 1949) (violation of $\S 8(d)$ no ground for $\S 301$ suit).

37. The Conference Committee discarded a provision in H.R. 3020, 1 LEG. Hrst. LArRA 241-2 (1948), which would have made such a strike an unfair labor practice. The Committee stated: "Once parties have made a collective bargaining contract the enforcement of that contract should be left to the usual processes of law and not to the National Labor Relations Board." H.R. CoNf. Rep. No. 510, 80th Cong., 1st Sess. 41 (1947).

38. Section $S(d)$ 's logical inconsistencies are resolved if it is applied only to strikes at the time of contract termination. Under this application, the waiting period in $\S 8(d)$ (1) would begin no earlier than the sixty days immediately before contract termination. And since the only strikes invalid under $\$ \$(d)$ (4) would occur during this sixty-day period, all guilty strikers would be denied reinstatement by statute. See text at notes 4 and 29 supra. 
resolved. ${ }^{39}$ Since a waiting period of sixty days at the termination of a contract was deemed sufficient for warning and cooling-off, there appears no sound reason to forbid a strike for months or years merely because a contract has not terminated. ${ }^{40}$ This is particularly true when the agreement specifically provides for modification coupled with the right to strike. ${ }^{11}$ Since Section $8(d)$ was a

39. See 93 Cong. Rec. 3955 (April 23, 1947), 2 NLRB, LEG. Hisr. LMRA 1015 (1948) (Taft: warning and mediation); 93 Cong. Rec. 5136 (May 12, 1947), 2 NLRB, LEG. Hist. LMRA 1479 (1948) (Hatch : cooling-off) ; 93 Cong. Rec. 5146 (May 12, 1947), 2 NLRB, LEG. Hisr. LMRA 1496 (1948) (Ball: warning); 93 Cong. Rec. 6542 (Junc 4, 1947), 1 NLRB, LEG. HIST. LMRA 887 (1948) (Madden : cooling-off) ; 93 Cong. Rec. 6662 (June 6, 1947), 2 NLRB, Leg. HIst. LMRA 1580 (1948) (Murray: cooling-off). See also Hartley, OUR New Natronal Labor Policy 121-2 (1948) (warning); International Union of Operating Engineers, Local No. 181 v. Dahlem Construction Co., 193 F.21 470, 473 (6th Cir. 1951) (mediation); Boeing Airplane Co. v. NLRB, 174 F.2d 988, 990 (D.C. Cir. 1949) (cooling-off).

For references in hearings to the fact that the waiting period was designed for warning, mediation, and cooling-off, see Hearings before Committee on Labor and Public Welfarc on S.55 and S.J. Res. 22, 80th Cong., 1st Sess. 273-75, 1146-50, 1389-90, 1544, 2010 (1947); Hearings before Committee on Education and Labor on H.R. 8, 80th Cong., 1st Sess. 210, 236, 2282, 2955, 3184 (1947).

40. During the congressional debates on the LMRA, there was no indication that $\S 8$ (d) would impose more than a sixty-day ban on strikes. See 93 Cong. Rec. 3955 (April 23, 1947), 2 NLRB, Leg. Hist. LMRA 1015 (1948) (Taft); 93 Cong. Rec. 4156 (April 25, 1947), 2 NLRB, LEg. Hrst. LMRA 1048 (1948) (Murray); 93 Cong. Rec. 5081 (May 9, 1947), 2 NLRB, LEG. Hist. IMRA 1408 (1948) (Ives); 93 Cong. Rec. 5137 (May 12, 1947), 2 NLRB, Leg. HIst. LMRA 1479 (1948) (Hatch). See especially the comments of Senator Ball after the President's veto: "I think ours is a very mild provision, which merely says to unions, 'You must have a 60 -day reopening clause in your contract.'" 93 CoNG. Rec. 7530 (1947).

At the hearing, no witness advocated more than sixty days notice before a strike, and no one was under the impression that a bargaining strike at any time would be prohibited for a period longer than sixty days. See, e.g., Hearings befare Committec on Educalion and Labor on H.R. 8, 80th Cong., 1st Sess. 8, 87, 131, 1071, 2264, 3099, 3845 (1947) ; Hearings before Committee on Labor and Public Welfare on S. 55 and S.J. Res. 22, 80th Cong,, 1st Sess. 1544, 1622-4, 2010, 2393 (1947).

41. None of the strikes in the three instant cases were in express breach of contract, since none of the contracts contained a no-strike clause. Local 49, United Packinghouse Workers, 89 N.L.R.B. 310, 311 (1950) ; Wilson \& Co., 105 N.L.R.B. No. 128, p. 4, 32 Lab. Rel. Ref. Man. 1371, 1372 (June 30, 1953) ; Lion Oil Co., 109 N.L.R.B. No. 106, p. 19 (August 5, 1954). The NLRB position appears to be that the right to strike is not waived except when explicitly provided for in the contract. Dorscy Trailers, Inc., 80 N.L.R.B. 478 (1948), enforcement denied in part, 179 F.2d 589 (5th Cir. 1950); Illinois Bell Telephone Co., 88 N.L.R.B. 1171, 1174 and n.11 (1950) ; Local 49, United Packinghouse Workers of America, CIO, 89 N.L.R.B. 310 (1950). See Isaacson, Enforceincm! of Labor Agreements by Economic Action, 6 NYU CONFERENCE ON LABOR 75-7 (1953).

However, some courts have stated that the contract itself, absent provisions to the contrary, creates the implication that the right to strike to change its terms has been waived while the contract is in force. See NLRB v. Dorsey Trailers, Inc., 179 F.2d 589 (5th Cir. 1950) (inclusion of grievance procedure in contract creates implication of waiver of right to strike over grievances until exhaustion of procedure). Sce NLRB v. Sands Mfg. Co., 
provision for warning and cooling-off, Congress probably intended it not to prohibit strikes during the terms of contracts but to prohibit strikes for sixty days after notice in all types of strike situations. ${ }^{22}$ Thus the only purpose of the "whichever is later" provision presumably was to prohibit a union from striking during the sixty-day notice period if this notice period extended beyond the

306 U.S. 332, 344 (1939). See also Isaacson, supre at 69, 74. The fact that the no-strilie clause is expressly bargained for in most contracts, see note 46 infra and 54 CoL. L. Rew. 1006 (1954), would seem to indicate that most employers and unions believe that it has some effect in limiting the union's right to strike.

Moreover, the strikes in Packinghouse Workers and Lion Oil were pursuant to amending clauses in the contracts. See text at notes 13 and 22 supra. Even if the waiver of the right to strike theory is accepted, there is no reason to believe that this implication extends to periods when the parties provide for contract modification. In Packinghouse Worlers, the employer, prior to the controversy, explicitly recognized the union's right to strike at reopening. See General Counsel's Exhibit 14, quoted in Brief for the NLRB, p. 4, Local No. 3; United Packinghouse Workers of America, CIO v. NLRB, 210 F.2d 325 (Sth Cir. 1954).

Finally, even if the strikes in the instant cases were in breach of contract, this does not mean they violated $\$ 8(d)$. See note 36 supra.

42. When the ambiguity in $\S \$(d)$ 's language with respect to strikes before contract termination was brought to the attention of Congress after passage of the LAIRA, attempts were made to amend $\$ 8(d)$ to indicate clearly Congress' intent to allow strikes after sixty days notice in all situations. See Report of Joint Committee on Labor Management Relations, Sen. Rep. No. 986, pt. 3, S0th Cong., 2d Sess. 62-3 (1948); Sex. Rep. No. 374, 81st Cong., 1st Sess. 45-6 (1949) (minority report). Senator Taft was in favor of amending the section: "[I]t is not clear that a strike after 60 days' notice under an annual reopening clause of a contract running for more than 1 year would not constitute a violation . . . . The amendment proposed below makes it clear that such a strike would not constitute an unfair labor practice." SEN. Rep. No. 99, pt. 2, S1st Cong., 1st Sess. 27 (1949). His amendment included provision for notice of a reopening strike in $\$ 8(d)(1)$ and struck: out the "whichever is later" clause in $\$ 8(\mathrm{~d})$ (4). Id. at 42 . S. 249 as amended by Tait passed the Senate, 95 Cong. REC. 8717 (1949), but never became law. S. 2650, the latest attempt at amendment, has been returned to committee 100 Cong. Rec 5859 (Aray 7, 1954). It amended $\S 8(d)$ but did not change the content of $\S 8(d)$ (1) through $8(d)(4)$. For test of the amendment, see 100 Cong. Rec. 75 (Jan. 11, 1954).

Besides the above interpretation that Congress intended $\$ \$(d)$ to prohibit strilkes for a maximum of sixty days in all situations, two other interpretations of $\$ S(d)$ 's legislative history are possible. The first is that taken by MIurdock in Wilson and Lion Oil, see notes 11 and 26 supra, that Congress intended the section to apply only to strikes at contract termination, and imposed no notice requirement on pre-termination bargaining strikes. However, if Congress' general purpose in passing $\$ \$(d)$ is conceded to be warning and coolingoff, see text at note 39 supra, it seems unreasonable to argue that Congress intended to provide warning only for strikes at contract termination.

The second possible interpretation is that Congress made $\$ \$(d)$ applieable only to strikes at contract termination because it assumed that $\S 8(\mathrm{~d})$ would prevent pre-termination bargaining strikes. This yields the same tesult as Packinglouse Worlscrs. However, this interpretation seems unsound, since nowhere in the hearings, reports, and debates on the LMIRA was it stated or implied that $\$ S(d)$ would prevent strilkes for a period longer than sixty days. See note 40 supra. The only sanction Congress imposed on pretermination bargaining strikes was the damage suit if the strike breached the contract. Sce text at notes 34-7 supra, and 52-3 infra. 
expiration date of the contract. ${ }^{43}$ Commentators have uniformly recognized no purpose or effect for Section 8(d) other than warning or cooling-off: ${ }^{44}$

The Eighth Circuit's approach in Packinghouse Workers threatens unfortunate results. Most collective bargaining contracts have provisions which permit amendment or reopening. ${ }^{45}$ Although a substantial majority of these also con* tain some form of no-strike clause, almost all of them either expressly or impliedly allow the union to strike at the time of amending.40 Packinghouse Workers, by barring such strikes, destroys the effectiveness of these amending provisions. ${ }^{47}$ Unions may thus find themselves bound to unsatisfactory terms for much longer periods than they originally contemplated. Moreover, unions bargaining for new contracts will find long-term agreements much less satisfactory without adequate amending clauses. Rather than lose the right to strike during the course of a long agreement, many unions may bargain for shortterm contracts or contracts of indefinite length, terminable upon sixty days notice. These shorter and less secure agreements will frustrate rather than encourage the aims of uninterrupted operation and industrial stability to which the Eighth Circuit gave its approval..$^{48}$

43. See statement of Senator Taft in 93 Cong. Rec. 3955 (April 23, 1947), 2 NLRB, LEG. Hist. LMRA 1015 (1948); Local No. 49, United Packinghouse Workers of America, CIO, 89 N.L.R.B. 310, 316-7 (1950).

44. See BNA, The New Labor Law 47 (1947); CCH, New Labor LAw $\| 45$ (1947); Gagliardo, Introduction To Collective Bargaining 177 (1953); Werne, The LAW of Labor Relations 132, 235 (1951) ; 2 Teller, Labor Disputes and Collective BargainING § 398.79, p. 108 (Supp. 1950). See also 93 Conc. REc. A2915-16 (1947) (Friendly); 93 Cong. Rec. A2977 (1947) (Stark) ; Hearings before Committec on Labor and Public Welfare on Revisions of LMRA, 83d Cong., 1st Sess. 263, 270 (NAM), 465 (CIO) (1953).

45. An amending clause permits a union to negotiate with management to modify any or all terms of the contract prior to termination. Approximately $80 \%$ of all collective bargaining agreements have some type of amending clause. P-H Unson CoNT. SERv. $\llbracket 53,630$ (1953). The reopening clause is a common type of amending clause, which is contained in approximately $50 \%$ of all agreements, see Labor-Management Contract Provisions 28 (U.S. Bur. Lab. Stat. Bull. No. 1022, 1951) (2,754 agreements analyzed) ; P-H UNION CONT. SERv. \{ 53,420 (1953), and limits the area of bargaining to wages and closely related fringe items. See P-H Union Cont. Serv. If 53,457 (1953). Amending clauses usually stipulate a specific date when bargaining may commence upon the election of either party, if notice is given. Some clauses, however, stipulate that a contract can be reopened or amended at any time, or after a specified date, or between specified dates, if notice is given. BNA Coli. Barg. Neg. \& Cont. Serv. 15:40 (1953); P-H Union Cont. Serv. $\llbracket 53,457$ (1953). For specimen clauses, see BNA Coll. Barg. Neg. \& Conx. Serv, $93: 12$ (1951).

46. Although $89 \%$ of contracts contain some form of no-strike clause, BNA CoLn. Barg. Neg. \& Cont. Serv. $15: 325$ (1954), 30\% explicitly allow a union to strike during amending negotiations, P-H Union Cont. Serv. II 53,390, 53,420, 53,396.1 (1953), and most agreements impliedly permit such a strike. 34 LAB. REL. REP. ANAL. 64 (1954); BNA Coll. Barg. Neg. \& Cont. Serv. $15: 325$ (1954).

47. See note 32 supra.

48. See Local No. 49, United Packinghouse Workers of America, CIO, 89 N.L.R.B. 310,314 (1950). Long-term contracts encourage industrial stability. See Gencral Motors Corp., 102 N.L.R.B. 1140, 1142 (1953). Because a contract with a reopening clause can bar a representation election for its entire term, shorter contracts make the union more vul- 
Lion Oil, although following the reasoning of Packinghouse W $W$ orkcrs, reaches a more justifiable conclusion by permitting unions to strike at the time of contract termination or modification but at no other time during the life of the contract. Since most contracts contain no-strike clauses preventing strilies except during amending periods, ${ }^{49}$ Lion Oil allows strikes during the only periods when they would normally take place. ${ }^{50}$ Furthermore, for contracts with year-long amending clauses similar to the one in Packinghouse IYorkcrs, Lion Oil allows strikes at any time upon sixty days' notice. ${ }^{31}$

However, Lion Oil is faulty in several respects. Because it states that bargaining strikes prior to contract termination violate Section $8(\mathrm{~d})$, it deprives unions with agreements which lack an amending clause of their right to strike during the life of these contracts. Moreover, although most agreements contain no-strike clauses, unions may strike in violation of these contracts if they are willing to risk suits for damages. ${ }^{52}$ Lion Oil follows Packinghouse Workers in flatly prohibiting these strikes by declaring them unfair labor practices. ${ }^{63}$ Finally, Lion Oil holds that Section $8(\mathrm{~d})(1)$ is satisfied by notice eight months in advance of a strike. ${ }^{54}$ This tends to shroud the exact time of the impending

nerable to decertification as bargaining representative Bath Iron Works Corp., 101 N.L.R.B. 849 (1952) ; Western Electric Co., 94 N.L.R.B. 54 (1951).

49. See note 46 supra.

50. Unions would normally be dissuaded from striking for bargaining purposes at other times because such a strike would breach a no-strike clause. See text at note 46 sopro. Breach of contract would open the union to a $\$ 301$ suit for damages, see note 36 supro, and since the NLRB maintains the policy that strikers participating in contract breaches are unprotected under the LMIRA, employees would lose their right to reinstatement. NLRB v. Rockaway News Supply Co., 345 U.S. 71 (1953); Joseph Dyson \& Sons, Inc, 72 N.L.R.B. 445 (1947) ; Scullin Steel Co., 65 N.L.R.B. 1294 (1946). Cf. NLRB v. Mastro Plastics Corp., 214 F.2d 462 (2d Cir. 1954) (no loss of reinstatement where strike was in response to employer's unfair labor practice). See generally ABA Committee on Improvement of Union-Employer Contracts, The No-Strike Clause, 21 Geo. Wasr. L. Rev. 127 (1952); Levinson, Breach of Contract Under the Taft-Hartley Aet, 2 Lafon L.J. 279 (1951) ; Note, 63 YALE L.J. 1186 (1954).

51. See note 13 supra. But see note 52 inffra.

52. The Norris-LaGuardia Act, 47 Stat. 70 (1932), 29 U.S.C. $\$ 101$ et scq. (1952), prevents the enjoining of strikes as a remedy for breach of contract. Alsoz S.S. Co. y. Ircilahon, 173 F.2d 567 (2d Cir. 1949); In re Third Ave. Transit Corp., 192 F.2d 971 (2d Cir. 1951).

Moreover, unions are seldom sued for breach of a collective bargaining agreement, and even these infrequent suits seldom result in damages being awarded. SErr. REp. No. \&6, pt. 3, pp. 30-2, 80th Cong., 2d Sess. (1948) ; 49 Mircr. L. Rev. 902 (1951) ; Isancson, Enforcement of Labor Agreements by Economic Action, 6 NYU Confzrence On Lasor 89 (1953).

However, if a strike violates $\S 8$ (d), it is an unfair labor practice. The LMRA specifically exempts injunctions for such strikes from the restrictions of the Norris-LaGuardia Act. 61 StAT. 149 (1947), 29 U.S.C. $\$ 160(\mathrm{~h})$ (1952).

53. See text at note 5 supra.

54. See text at notes 22 and 26 supra. The union in Lion Oil, although it did not supply a second statutory notice of its impending strike, unoficially warned the employer of 
strike in uncertainty, thus frustrating the aim of Section 8 (d) to provide adcquate strike warning. Although it would be impractical to require the union to strike precisely sixty days after notice, ${ }^{, 5}$ it seems unreasonable to allow grossly premature notice to act as compliance with the warning requirements of Section 8(d).

Parties to collective bargaining agreements can avoid the impact of Packinghouse Workers and Lion Oil when drafting new contracts. Unions desiring to preserve their right to strike can bargain for short-term agreements or contracts of indefinite length terminable upon sixty days notice. ${ }^{50}$ Or unions and employers desiring both to retain the benefits of a long-term contract and to allow the right to strike during the amending or reopening period may be able to draft their collective bargaining agreements in the form of two contracts. Contract I, for a long term, would include all provisions which the parties intended to remain unchanged, such as pensions and union security. It would also include a clause continuing the contract during any strike. Contract II would cover only those basic provisions, such as wages, formerly subject to modification, and would terminate on the former amending date. Upon the expiration of Contract II, the union could strike to modify its terms after giving sixty days' notice. Since such a strike would not modify Contract I, and since it would take place after the termination of Contract II, it would fully satisfy even the literal interpretation given Section 8(d)(4) in Packinghousc Workers. ${ }^{57}$

The Eighth Circuit, on review of Lion Oil, ${ }^{58}$ should overrule or modify its holding in Packinghouse Workers, which misconstrues both the purpose and language of Section 8(d) ${ }^{59}$ If Packinghouse Workers stands, Congress should

the strike 11 weeks before it occurred. Lion Oil Co., 109 N.L.R.B. No. 106, p. 2, 34 LAd. REL. Ref. Man. 1410, 1411 (August 5, 1954).

55. The strikes in Wilson and Packinghouse Workers occurred 12 and 13 weeks, respectively, after notice. See text at notes 9 and 14 supra. This notice would secm to be sufficiently close to the time of the strike to provide adequate warning to the employer.

56. For typical clauses, see P-H UnION Cont. SERv. If 53,630-1 (1953); BNA Coll. Barg. Neg. \& Cont. Serv. $15: 75,36: 11,36: 12$ (1952).

57. The Studebaker Corp. and the United Auto Workers, CIO, have two agreements, similar to Contracts I and II. See BNA Coll. BARg. Neg. \& CoNt. Serv. 36:12 (1952).

Another contractual arrangement to achieve the same result would be a long-term contract with a reopening clause listing provisions and dates for negotiations, with a stipulation that the entire contract would terminate if no agreement was reached on the reopened provisions. Communication to the Yale Law Journal from John L. Cockrill, Counsel for Wilson \& Co., dated June 10, 1954, in Yale Law Library. For specimen clause, sec P-H UNION CONT. SERv. $\{$ 53,457.25 (1953).

58. Petition for review of Lion Oil was filed with the Eighth Circuit on August 23, 1954. Communication to the Yale Law Journal from Jeff Davis, Counsel for Lion Oil Co., dated September 29, 1954, in Yale Law Library.

59. A decision overruling Packinghouse Workers and allowing a pre-termination bargaining strike upon 60 days' notice, with or without a reopening clause, would be preferred. However, the court might accept Lion Oil, thereby allowing a pre-termination strike pursuant to an amending clause, and distinguish Packinghouse Workers on the ground that 
clarify Section $8(d)$ by explicitly allowing strikes during the term of collective bargaining contracts upon sixty days' notice. ${ }^{60}$

it never considered the validity of a pre-termination bargaining strike pursuant to an amending clause. See note 13 supra.

60. Congress should amend $\S \$(d)(4)$ by deleting the words "... or until the expiration date of such contract, whichever occurs later." Section $8(d)(1)$ should also be amended to provide that notice must be given sixty days prior to the time when the union desires to strike, rather than sixty days prior to the expiration of the contract. If Congress desires to prohibit certain strikes during the term of an agreement, such as strikes which fail to comply with amending clauses, it should do so by specific statutory enactment.

For suggested amendments to $\$ \$($ d), see SEN. REP. No. 99, pt. 2, 81st Cong., 1st Sess. 42 (1949); Sen. Rep. No. 986, pt. 3, 80th Cong., 2d Sess. $62-3$ (1948). 